\title{
Cash Waqf Linked Sukuk as an Instrument of National-Scale Community Economic Empowerment Based on a Functionalist Sociology Perspective
}

\author{
Muhammad Abdulloh ${ }^{1 *}$, I'zaz Habibah ${ }^{2}$, Agung Slamet Sukardi ${ }^{3}$, and Moh. Nurul Qomar ${ }^{4}$ \\ ${ }^{1}$ Zakat and waqf management, Faculty of Islamic Economics and Business, Islamic State Institute of \\ Kudus, Central Java, Indonesia. \\ ${ }^{2}$ Syaria Business management, Faculty of Islamic Economics and Business, Islamic State Institute of \\ Kudus, Central Java, Indonesia \\ ${ }^{3}$ Lecturer of Syaria Economic, Faculty of Islamic Economics and Business, Islamic State Institute of \\ Kudus, Central Java, Indonesia \\ ${ }^{4}$ Head of zakat and waqf management study program , Faculty of Islamic Economics and Business, \\ Islamic State Institute of Kudus, Central Java, Indonesia
}

\begin{abstract}
Indonesia is a country with a Muslim majority which makes the potential of Waqf (Islamic philanthropy) very large and needs to be developed for better management in empowering the community in the productive business sector. This study discusses waqf sukuk which is an innovation in collecting cash waqf by the Ministry of Finance and Indonesian Waqf Agency which is then used for broad economic empowerment which is in line with the potential amount of cash waqf in Indonesia. This study aims to find a sustainable productive business mechanism based on statistics on the development of business sector and uses qualitative analysis methods using a functionalist sociology perspective on waqf management agency and institutions in Indonesia. This study found that productive business that can be done is in the creative economy sector and the manufacturing industry with three stages, namely the beginning, transition, and the end with several considerations, namely capital, human resources, technological developments, and changing times. With this mechanism and assuming that the waqf management agency or institution can be sustainable and centrally coordinated and mutually supportive, national-scale economic empowerment can be achieved and sustainable productive efforts will create community economic independence based on cash waqf linked sukuk (CWLS).
\end{abstract}

Keywords: waqf sukuk; productive business; community development; functionalist sociology

\footnotetext{
* Corresponding author: muhammadabdulloh0704@gmail.com
} 


\section{$A \mathrm{IC} \quad$ Annual International Conference \\ on Islamic Economics and Business, 2021}

\section{Introduction}

Indonesia has the fourth largest population in the world with a population of 272,229,372. Of this number, Indonesia is also one of the countries with the largest number of Muslims, reaching 236.53 million people or equivalent to $86.88 \%$ of the population (Kemendagri, 2021). Whose religious teachings contain worship that can be used as a means of faith and concern for fellow creatures of God or fellow human beings Islam. Worship in this case can be categorized into two types, namely obligatory and non-obligatory worship. One example of obligatory worship is zakat. In Indonesia, zakat is shaded by a state institution, namely the National Amil Zakat Agency, which was later shortened to BAZNAS, then worship is not obligatory. One example is waqf which is sheltered by the Indonesian Waqf Agency, which is abbreviated as BWI.

The waqf management agency or institution has a very large role in empowering the community by using the funds that have been collected (Syauqi, 2014). Therefore, the waqf management agency or institution must have synchronization and sustainability in a structured way so that they can jointly advance the nation by managing through structured and sustainable productive efforts so that each manager has a core plan (master plan) together with the aim of advancing the economy in scope national.

Empowerment and management of waqf have not been better developed by stateestablished bodies or non-governmental organizations that have not yet reached the point of maximum collection and management, which so far has great potential. One of the causes of this not being optimal in collecting funds is because there is no real side of profit and profit between the people who want to waqf and the waqf manager and the clarity of the guarantee for the cash waqf. In addition, it has not optimized the various facilities that have existed according to the development of the era. With the era of technology as it is today, it should be able to make it easier for people who want to channel funds and supervise the use of their funds.

Through the waqf collection mechanism that has been made, it is necessary to have a management mechanism that will be used by the waqf sukuk managers together in managing a sustainable and sustainable productive business in every region in Indonesia so that the pattern of community empowerment based on sharia finance will help the state in advancing the nation. nationally.

\section{Method}

This study uses library research using qualitative analysis methods on various reference sources for research journals that have been carried out and are included in the bibliography of this study. Data collection and analysis was based on all material coverage from reference sources contained in the bibliography of this research and analyzed in relation to productive efforts for community economic empowerment.

This study uses a functionalist sociology perspective. This perspective considers that a group or institution in this case waqf managers is seen as a network that collaborates regularly in its performance with a set of guidelines that are regulated or adhered to so as to create harmony and balance in performance with a stable and balanced system (Syawaludin, 2015). So that the results of this study will be able to achieve the expected goals with the guidelines that have been produced in this study. 


\section{Result and Discussion}

\subsection{Sukuk Waqf (cash waqf linked sukuk)}

\subsubsection{Collection System}

Waqf sukuk or known as cash waqf linked sukuk are a form and synergy between Bank Indonesia and BWI in optimizing the magnitude of cash waqf opportunities in Indonesia (Saptono, 2018). Cash waqf linked sukuk are managed based on sharia principles with the issuance of a sharia-compliant statement by the Sharia Supervisory Board number B285/DSN-MUI/IV/2021 on April 7, 2021 (Ministry of Finance, 2021). Therefore, this new breakthrough must get more enthusiasm from all parties, especially socializing for wakif and nadzir so that the sharia financial system and worship can be strong and provide benefits for the people and prove that Indonesia is a country with a majority Muslim who is obedient and has concern for others. as well as the environment.

a. Wakif

Wakif in the case of this sukuk gets facilities and guarantees for waqf funds that are distributed and will be returned in full within a predetermined period of time and get a coupon of a predetermined percentage of the amount of waqf funds which are then distributed to nadzir and managed by him. For this convenience, waqf can be waqf through sukuk with the following flow:

- Visit the nearest BWI-appointed sharia bank branch office.

- Fill in the waqf pledge deed form and order

- Open a savings account, government securities account and single investor identification (SID).

- Put money in a savings account.

- Then follow the path that has been determined by the Islamic bank.

b. Nadzir

Nadzir's role in this management will determine the progress and direction of the development of waqf-based community empowerment. Tenacity and innovation are needed so that the amount of funds that are opportunities and have been collected can be well coordinated. Nadzir can receive or manage this waqf sukuk if:

- Have permission from BWI or are nadzir from BWI

- As an institution that is trusted or mandated by Islamic banks in its management and registered as a waqf institution at BWI

- Nadzir receives periodically according to the provisions of Islamic banks.

- Nadzir reports periodically on the use or management of the finances he manages.

\subsubsection{Characteristics of waqf sukuk (CWLS)}

This new breakthrough in investment and worship packaged in retail waqf sukuk has several main characteristics that also distinguish it from other sukuk issued by the government, namely:

a. In accordance with Sharia Principles

Because the context of this retail waqf sukuk is an investment in cash waqf whose rewards are used to empower people or worship, it must have sharia principles, this is what distinguishes it from sukuk in general. This compliance with sharia principles is based on a statement in accordance with sharia by the Sharia Supervisory Board number B285/DSN-MUI/IV/2021 on April 7, 2021.

b. Cannot be traded in the secondary market 


\section{$A I \overline{C E B} \quad$ Annual International Conference \\ on Islamic Economics and Business, 2021}

The secondary market is a market where the sale and purchase of securities previously marketed in the primary market and then listed on the Indonesia Stock Exchange.

1) 2 Years Tenor

Retail waqf sukuk issued by the government have a tenor of 2 years or in other words this waqf has a term with the stipulation that in 2 years the money will return $100 \%$ to the wakif.

2) There is a minimum order

The minimum order requirement is 1 million rupiah and there is no maximum limit. With this, people can save their money while worshiping which money will be returned in full.

3) Intended for individual or institutional wakif

4) Fixed and sure rewards

The rewards given are fixed and definite, which means that after the period of 2 years is over, there will be rewards which are then distributed by Nadzir for community empowerment or social activities with the amount determined by the government when ordering retail waqf sukuk (MoF: 2021).

\subsubsection{The advantages of retail waqf sukuk (CWLS)}

Retail waqf sukuk have various advantages which of course can attract investors or wakif in placing orders, there are several advantages, namely:

a. Easy

Waqf is easy to do just by going to a financial institution appointed by the government to market the sukuk, which have spread to all corners of Indonesia.

b. Productive

Rewards are used to finance social activities and productive businesses so that they can help the people's economy gradually and sustainably

c. Trust

Management is carried out in a transparent and accountable manner so that trust can be obtained and can directly monitor the usefulness of the funds that have been distributed.

d. Safe and intact

The security of funds by the wakif is guaranteed to be safe and intact because it is the state or government that issues securities, so that the security is directly guaranteed by the government which later after the period is over, the money will be returned in full or $100 \%$.

\subsubsection{The purpose of retail waqf sukuk (CWLS)}

The issuance of retail waqf sukuk has several main objectives where the government has facilitated convenience to the community with safe and productive guarantees for the benefit of the people. These objectives are:

a. Development and strengthening of the waqf ecosystem in Indonesia

b. Development of productive waqf on a national scale

c. Creating and supporting the waqf movement in the national scope

d. Social investment development

e. Encouraging independent and sustainable national economic growth. 


\section{$A I C \overline{I E B}$ Annual International Conference \\ on Islamic Economics and Business, 2021}

\subsection{Management of waqf sukuk as community empowerment on a national scale}

\subsubsection{Industry growth statistics}

Indonesia has experienced good economic growth from year to year. The economic growth was seen in various sectors, some sectors experienced very large and stable growth, giving rise to opportunities to be seen further, especially when related to the management of waqf sukuk in Indonesia.

Table 1. Indonesia's economic growth 2016-2020

\begin{tabular}{lccccccc}
\hline & 2016 & 2017 & 2018 & 2019 & 2020 & & \\
\hline Gross domestic product & 5.0 & 5.1 & 5.2 & 4.97 & 3,73 & & \\
\hline Household consumption & 5.0 & 4.9 & 5.1 & 5.0 & -3.61 & & \\
\hline Agriculture, forestry, plantation, & & 3.4 & 3.9 & 3.9 & 4.3 & 5.8 & \\
\hline \multicolumn{1}{c}{ and fishery } & & & & & & \\
\hline wholesale and retail trade; repair & 4.0 & 4.5 & 5.0 & 4.2 & 3.72 & \\
Processing industry & & 4.3 & 4.3 & 4.3 & 3.7 & 2.06 \\
\hline
\end{tabular}

Source: BPS:2021, Processed.

From the table, it can be seen that in general there has been an increase or stability. The latest data in 2020 has decreased on average due to the outbreak of the COVID-19 pandemic. So from the table in the last 5 years, there has been a good growth rate, namely household consumption and agriculture which includes creative and manufacturing industries, which have great opportunities to be developed further.

Broadly speaking, there are 2 industrial sectors which in recent years have had good growth rates, namely the manufacturing industry and the creative economy industry. With the development of technology as it is today, these two sectors are growing rapidly and can even become one of the largest sources of Indonesia's GDP. To see the growth of the creative economy, the following is a diagram of the growth of the creative economy

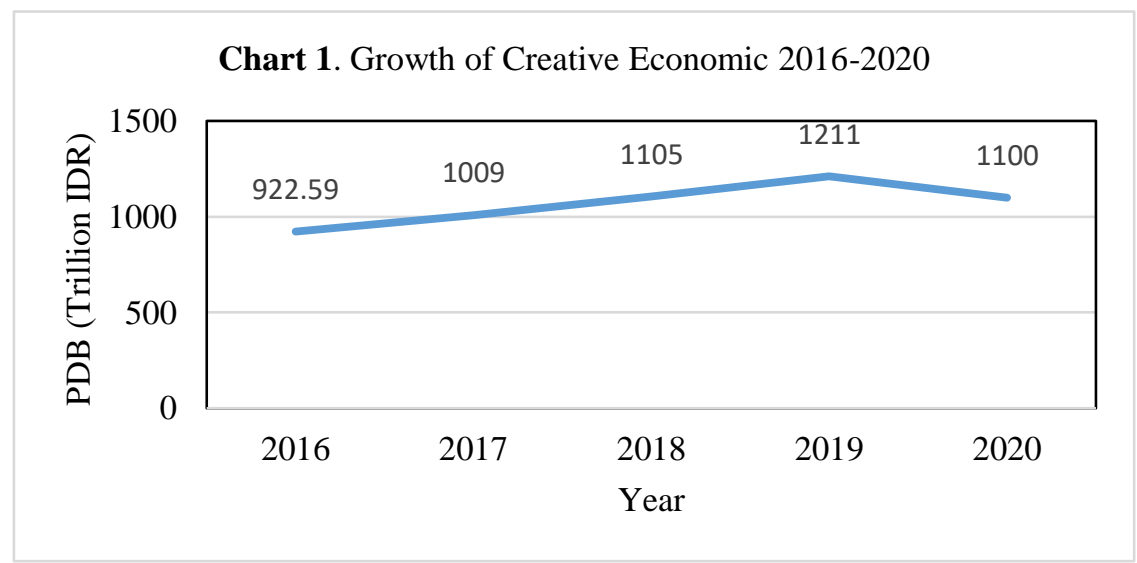

Source: Indonesian Creative Economy Agency

The creative economy industry in Indonesia continues to experience a significant increase so that this industry becomes the main focus of the preparation of business systematics for the empowerment of the waqf sukuk-based national economy. In the creative economy industry, there are many things that have great opportunities along with the times and 
increasingly advanced technology. Therefore, independence must be created and the large role of social funds by Muslims, especially sukuk, waqf, can be managed properly.

\subsubsection{The master plan for community empowerment based on cash waqf linked sukuk}

Indonesia has a fairly high labor force compared to its job opportunities. The Central Statistics Agency recorded the number of the workforce in Indonesia in February 2020 as many as 137.91 million people. That number increased by 1.73 million people compared to February 2019. While at the same time the number of unemployed people increased by 60,000 people (BPS: 2020). If employment opportunities in Indonesia do not increase to match the workforce in Indonesia, unemployment will increase. Therefore, this productive waqf system has an important role in providing job opportunities on a national scale with coordination lines for each region to touch the frontier and remote areas of Indonesia.

With the collection of productive funds with guaranteed waqf sukuk above, the next step is regarding effective and targeted management patterns based on the competence of managers. The bigger the project to be run, the higher the management qualification standard. In the future, state institutions that have rights in this matter can determine it. With these funds, the main objective in this research is the management of waqf sukuk as a national scale community empowerment. Therefore, it can be concluded that the productive business scheme to achieve this is as follows:

a. Early (first) productive business

Productive businesses at this stage use the current financial condition and collection. With this condition, the existing productive funds are used for small-scale productive businesses (each region with advantages or potential for a certain type of productive business) then managed and developed every time so that each profit period will be divided into 4 things, namely employee salaries, business expansion, socio-religious activities, and productive business savings that are gathered into one, namely at the central management. The role of the central manager to the regional manager is the supervisor and evaluator so that the business carried out can develop each period. The efforts in this first stage are as follows:

1) Marketing/trading

This business can be started in stages with additional capital or completely waqf. This business can be managed with branches in each region. This type of business is also adapted to each respective region. The basic step is the creation of a grocery store in each village with the manager through a skill selection system. After running and it was felt that the productive business savings within the scope of 1 sub-district were sufficient to make a minimarket, the funds were used to make a mini market. After that, within the scope of the district or province, the productive business savings funds are sufficient to make a super market, so this production can be carried out.

In this marketing system, what will distinguish it from business in general is that local community products can also be marketed in this business sector with terms and conditions adapted to existing conditions. So that in addition to empowering workers (opening job vacancies) this system also empowers regional expertise or work which can later be related to the tourism sector.

The role of state agencies in this case is to control human error or conflict of interest factors that can disrupt the financial cycle or business development. Evaluate each place of business in order to control the path of business development.

2) Advertising

The world of advertising has great potential that can be utilized better as well as to boost the name or existence of various waqf institutions. This business can be started 


\section{$A \overline{I E B}$ Annual International Conference \\ on Islamic Economics and Business, 2021}

by using social media as a product of the advertising marketing, this can use a paid promote system, namely by publishing media simultaneously in each member's account. Members who publish are tailored to the target market of users of this service. After this system is stable, the next step is to expand in various media from television, radio, newspapers, online newspapers, and various social media or entertainment by collaborating with various parties, in this case the business acts as an advertising agency. There are several divisions in this advertising business, namely:

- Product design: this division serves the creation of visual advertising designs that will be displayed according to the wishes of service users

- Photography: serving the making of photos or videos related to advertisements that will be used. This division does various things related to advertising products before being published in various relevant media and approved by users

- Publisher: this division is tasked with collaborating with related parties until orders from users are completed

3) Culinary

Psychic mental conditions can affect a person's performance in his daily life. The more busy and saturated a person needs to be refreshed to get through his busy day. This opens up opportunities in culinary tourism where the concept of culinary tourism uses the concept of soothing natural scenery as is currently a trend that is likely to continue along with the busyness of the times. The concept of this culinary business is by: Creating a business or national standard brand with a franchise business concept. Where there are third parties in carrying out their business with various provisions, namely:

- Has a charming natural view

- Having a path or tracking to the location is adequate

- A mature concept according to the environmental conditions where the business will be made

- Located in an area with minimal competition that can increase business opportunities.

After the fulfillment of these conditions, this franchise culinary business will cooperate with positive advertising efforts to promote the beauty and existence of this place in the future.

b. Productive business in the intermediate stage (second)

This second stage of productive business requires a large amount of capital so that it can be run after the first stage goes well and has adequate productive business savings. Some of these efforts are as follows:

1) Clothes

The clothing product industry is currently promising because the opportunities for model innovation are strongly influenced by the times, besides that the business climate is quite stable if you can see market opportunities and the development of clothing models over time. This line of business is in the form of a limited liability company or PT with the scope of a district or province with a location adjusted to possible conditions in terms of wages, labor, supporting infrastructure, and market prospects for clothing sales. In making this business, it uses a pattern of empowering vocational high school graduates who have a major in fashion and collaborates with these high schools. With feedback, namely:

- While still studying, participants were taught about the work climate in the company.

- Students are given the opportunity to submit designs about clothing which, if later accepted, will be given coaching money or scholarships 


\section{$A \mathrm{IC} \quad$ Annual International Conference \\ on Islamic Economics and Business, 2021}

- After students graduate, they will be invited to work according to their interests and talents with terms and conditions according to the times

2) Goods production company

With the existence of a productive business in the marketing sector, this type of production business has more opportunities than general marketing in various types of convenience stores. In addition, the consideration is in which sector the company will move. Because in essence the main goal is for the empowerment of the community and Indonesia, this company will later be engaged in the production of local products with a national or foreign market share so that there are several criteria that must be considered, namely:

- The company has rights to supporting equipment and obligations to procure production goods.

- Production is carried out by local product owners

- The company monitors product and packaging quality

- The company does product marketing

With the attention of the waqf management system to this regional work, the existence that is raised will make the market passion increase because there are various names of trusted institutions that cover or shelter it. In addition to aiming for community empowerment, it also aims to ensure that the original products of this nation are not sluggish in marketing.

This type of company adapts each institution to the area it manages and can cooperate with local governments so that good cooperation arises to realize these goals together.

c. The final (third) productive business

This final stage is the culmination of a productive business with waqf-based management. This business is with a national level and market goals to foreign countries. The focus on this business is as follows:

1) Technology

The current era is very close to technology and almost all fields are computerized so this is the main opportunity for technicians in this field. The manager's role in this field is to create a computerized company using native Indonesian workers with international level innovation power that is expected to compete with foreign markets. At a minimum, the initial target of this business is to reach the domestic market in the following areas:

- Home electronic products with one integrated system. This product is concerned with making all household items connected to the internet and can be used only by using a device.

- For gadgets or gadgets, the opportunity for this product is very high so this is the first step to dominate the electronic market in Indonesia. This device factory is not merely a production factory that already exists in Batam, Riau Islands. But all the supporting components are the work of the nation's children. It is not impossible to achieve this if it is based on mature steps and full of innovation work.

2) Automotive

In the future, the automotive market will switch to electric-powered vehicles and Indonesia is rich in nickel, which is the basic material for making batteries. This innovation, of course, must cooperate with various parties, including the government. In the manufacture of this company also requires a variety of experts which of course requires a very large cost if calculated from research to mass production. Therefore, this productive business is in the final stage which will receive an injection of funds from the smallest business to developing businesses located in each region. 


\section{$A \mathrm{IC} \quad$ Annual International Conference \\ on Islamic Economics and Business, 2021}

\section{Conclusion}

Retail waqf sukuk have enormous management opportunities, so a master plan is needed that can be used on a national scale and used as management guidelines by waqf institutions in every region in Indonesia. The ziswaf management institution which in functionalist sociology has a very large role in order to work in a coordinated and sustainable manner between institutions whose main goal is community empowerment by creating selfemployment independence and making the people's economy improve in a sustainable and broadly structured manner with a national scope.

This study finds several steps in a structured and sustainable manner with a core in the creative and manufacturing economic industry sectors by looking at year of year (YoY) economic growth. So that the main plan is adapted to the development of an increasingly pluralistic era and takes into account the factual conditions that occur in the current waqf management institution.

\section{References}

Atabik, Ahmad. (2014). Manajemen Pengelolaan Wakaf Tunai di Indonesia. Ziswaf, 1(1), 83-107.

Azhar, Kholidah., \& Zainal, Arifin. (2011). Faktor Faktor yang Memengaruhi Penyerapan Tenaga Kerja Industri Manufaktur Besar dan Menengah pada Tingkat Kabupaten/Kota di Jawa Timur. Jurnal Ekonomi Pembangunan, 9(1), 91-106. DOI: https://doi.org/10.22219/jep.v9i1.3648

Direktorat perencanaan makro dan analisis statistik. (2020). Perkembangan Ekonomi Indonesia dan Dunia. Badan Pusat Statistik. 4(1).

Himam, Nadiah S., \& Umam, Khoirul. (2018). Modelling Sukuk Waqf for Pesantren Economic Development. Journal of Islamic Economics and Philanthropy. 1(3), 123. DOI: http://dx.doi.org/10.21111/jiep.v1i3.2556

Ilmiah, Dunyati. (2019). Optimalisasi asset wakaf melalui sukuk wakaf di indonesia. Jurnal ekonomi syariah indonesia, 9(2), 138-146. DOI: http://dx.doi.org/10.21927/jesi.2019.9(2).127-137

Indra, Sukma. \& Hakim, Muhammad L. (2020). Pemberdayagunaan Imbalan Hasil Wakaf Uang Melalui Sukuk: Regulasi, Implementasi, Dan Modelnya Untuk Pemberdayagunaan Usaha Mikro, Kecil, Dan Menengah Di Indonesia. Sosio Informa, 6(3), 264-279.

Mai, Muhamad U., \& Setiawan. (2020). Pengaruh Struktur Modal Terhadap Kinerja Perusahaan pada Industri Manufaktur Kriteria Syariah di Bursa Efek Indonesia. Jurnal Riset Akuntansi dan Keuangan. 8(1), 159-170. DOI: https://doi.org/10.17509/jrak.v8i1.20065

Maspupah, Ima., \& Hasanah, Shofia M. (2016). Penguatan Filantropi Islam Melalui Optimalisasi Wakaf Berbasis Sukuk. Journal of Islamic Economics Lariba. 2(2), 25-38.

Maunah, Binti. (2016). Pendidikan dalam Perspektif Struktural Fungsional. Cendekia, 10(2), 159-178.

Nugroho, Yoga D, \& Wahyuni, Krismanti T. (2019). Aglomerasi dan Dinamika Industri Manufaktur pada Era Revolusi Industri 4.0 di Koridor Ekonomi Jawa. Seminar Nasional Official Statistics.

Nurochim, Siti N., \& Nurochim. (2020). Sekolah : Kajian Teoretik Perspektif Sosiologi Organisasi. Indonesian Journal of Social Science Education (IJSSE), 2(1), 66-81. DOI: http://dx.doi.org/10.29300/ijsse.v2i1.2716 
Omar, Hydzulkifli H., \& Rahman, Asmak Ab. (2013). Aplikasi Sukuk dalam Usaha Melestarikan Aset Wakaf: Pengalaman Pemegang Amanah Wakaf Terpilih. Jurnal Syariah. 21(2), 89-116.

Purnomo, Rochmat A. (2016). Ekonomi Kreatif: Pilar Pembangunan Indonesia. Surakarta: Ziyad Visi Media.

Rahmi, Asri Noer. (2018). Perkembangan Industri Ekonomi Kreatif Dan Pengaruhnya Terhadap Perekonomian Di Indonesia. Seminar Nasional Sistem Informasi.

Saptono, Imam T. (2018). Pengembangan Instrumen Wakaf Berbasis Investasi Sosial Studi Wakaf Linkeded Sukuk. Badan Wakaf Indonesia, 11(2), 117-128. DOI: https://doi.org/10.47411/al-awqaf.v11i2.20

Shofa, I. \& Nugroho, D. (2018). Pertumbuhan Dan Strategi Pengembangan Ekonomi Kreatif Kota Malang. Jurnal Pangripta, 1(1), 75-85.

Sholihah, Irma M., Syaparuddin., \& Nurhayani. (2017). Analisis Investasi Sektor Industri Manufaktur, Pengaruhnya Terhadap Pertumbuhan Ekonomi dan Penyerapan Tenaga Kerja di Indonesia. Jurnal Paradigma Ekonomika, 12(1), 11-24. DOI: https://dx.doi.org/10.22437/paradigma.v12i1.3930

Sholihin, Muhammad R., Arianto, Wahyu., \& Khasanah, Dina F. (2018). Keunggulan Sosial Media dalam Perkembangan Ekonomi Kreatif Era Digital di Indonesia. Prosiding $4^{\text {th }}$ Seminar Nasional dan Call For Paper Fakultas Ekonomi Universitas Muhammadiyah Jember, 149-160.

Suprihandani, Miya dewi., Masyhuri, mohammad ali., \& Pritiwantiyasih. (2019). Analisis Kinerja Keuangan Perusahaan Sektor Industri Manufaktur yang Melakukan Hedging di Bursa Efek Indonesia. Media Mahardika, 17(3), 500-517. DOI: http://dx.doi.org/10.29062/mahardika.v17i3.108

Syairozi, M imam. \& Cahya, Septyan Budy. (2016). Sukuk Al Intifa'a: Integritas Sukuk dan Wakaf dalam Meningkatkan Produktifitas Sektor Wakaf Pendorong Investasi pada Pasar Modal Syariah. Jurnal Penelitian Ilmu Manajemen, 2(2), 386-397.

DOI: http://dx.doi.org/10.30736\%2Fjpim.v2i2.49

Syauqi, Muhammad A. (2014). Optimalisasi Pengelolaan Wakaf Uang untuk Kesejahteraan Umum. Kanun Jurnal Ilmu Hukum. (63), 370-383.

Syawaludin, Mohammad. (2015). Kontribusi Teori Fungsionalisme Struktural Parson: Pengelolaan Sistem Sosial Marga di Sumatera. Sosiologi Reflektif, 10(1), 175198.

Wahyudi, dicky., Azwari, Peny C., Alfajr, Achmad., \& Septiani, Sandra D. (2018). Sinergitas Organisasi Publik Dengan Mengimplementasikan Sukuk Wakaf Melalui Pembentukan Halal Center Insdutry. Simposium Nasional Keuangan Negara.

Wulansari, Dewi. (2013). Sosiologi- Konsep dan Teori. Bandung: Refika Aditama.

Zainal, Veinthzal rivai.(2016). Pengelolaan dan pengembangan wakaf produktif. Badan Wakaf Indonesia, 9(1), 1-16. DOI: https://doi.org/10.47411/al-awqaf.v9i1.32

Kemendagri. (2021). Kementrian Dalam Negeri.

Kemenkeu. (2021). Kementrian Keuangan Republik Indonesia.

Saptono, I. T. (2018). Pengembangan instrumen wakaf berbasis investasi sosial studi wakaf linkeded sukuk. Al-Awqaf: Jurnal Wakaf Dan Ekonomi Islam, 11(2), 117-128.

Syauqi, M. A. (2014). Optimalisasi Pengelolaan Wakaf Uang untuk Kesejahteraan Umum. Kanun: Jurnal Ilmu Hukum, 16(2), 369-383. https://doi.org/10.24815/kanun.v16i2.6036

Syawaludin, M. (2015). Pengelolaan Sistem Sosial Marga Di Sumatera Selatan: Telaah atas Kontribusi Teori Fungsionalisme Struktural Parsons. Jurnal Sosiologi Reflektif, 10(2). https://doi.org/10.14421/jsr.v10i2.1152 